\title{
Regulation of polyphosphate kinase gene expression in Acinetobacter baumannii 252
}

\author{
Julie-Ann Gavigan, Leonard M. Marshall and Alan D. W. Dobson
}

Author for correspondence: Alan D. W. Dobson. Tel: +353 21 902743. Fax: +35321903101. e-mail: a.dobson@ucc.ie

Microbiology Department and National Food Biotechnology Centre, National University of Ireland Cork, Cork, Ireland

\section{A strain of Acinetobacter baumannii cultured in butyric acid media was found to take up phosphate following a period of phosphate release. PCR was used to clone the polyphosphate kinase (ppk) gene from the strain. The promoter for the ppk gene was functional in the heterologous Escherichia coli host. Using RT-PCR, transcription of the ppk gene was found to be regulated by phosphate concentration.}

Keywords: Acinetobacter baumannii, polyphosphate kinase, RT-PCR

\section{INTRODUCTION}

Polyphosphate is a linear polymer of several orthophosphate residues, linked by high-energy phosphoanhydride bonds. While possibly a precursor in prebiotic evolution, polyphosphate is now found in volcanic condensates, oceanic steam vents and in a wide variety of organisms (Kulaev, 1979). Its ubiquity suggests an essential physiological role; however no such function has yet been identified. Functions may depend on the organism and the physiological conditions as previously reviewed (Kornberg, 1995; Wood \& Clark, 1988). Different functions which have been suggested include: (1) an energy or phosphate store, (2) a substitute for ATP in some reactions and in the chelation of ions (Keasling \& Hupf, 1996), (3) a buffer for the maintenance of constant intracellular phosphate concentration, and (4) a role in DNA uptake in Escherichia coli cells (Castuma et al., 1995; Reusch \& Sadoff, 1988).

In E. coli there are at least 38 genes involved in phosphorus assimilation, which are organized as one regulon (the pho regulon) and are therefore subject to a common molecular control. Genes of the pho regulon are regulated by a two-component regulatory system composed of a response regulator, $\mathrm{PhoB}$, and a sensor kinase, PhoR. Expression of the pho regulon is repressed when the extracellular phosphate concentration is in excess, and the genes of this regulon have a controlling promoter element called the pho box (Wanner, 1996). In E. coli, the enzyme polyphosphate kinase (Ppk) polymer-

Abbreviations: EBPR, enhanced biological phosphate removal; RACE, rapid amplification of CDNA ends.

The GenBank accession number for the sequence determined in this work is AF116175. izes the terminal phosphate of ATP into poly $(\mathrm{P})$ in a freely reversible reaction:

$\operatorname{poly}\left(\mathrm{P}_{\mathrm{n}}\right)+\mathrm{ADP} \rightleftharpoons \mathrm{ATP}+\operatorname{poly}\left(\mathrm{P}_{\mathrm{n}-1}\right)$.

There is, however, disagreement as to whether the gene responsible, $p p k$, is controlled by the $p h o$ regulon (Kato et al., 1993a; Torriani-Gorini, 1994) or not (Wanner, 1996).

The polyphosphate kinase ( $p p k$ ) gene has been cloned and sequenced in several species including Acinetobacter sp. strain ADP1, Neisseria meningitidis, Klebsiella aerogenes and E. coli, in which it was found to be located in the same operon as the gene for exopolyphosphatase ( $p p x)$ (Ahn \& Kornberg, 1990; Akiyama et al., 1992, 1993). Transcription of the $p p k$ gene is induced by phosphate starvation in Acinetobacter sp. ADP1, whereby it is switched off in cells growing in conditions of phosphate abundance and switched on under phosphate-limiting conditions (Geißdörfer et al., 1998). $K$. aerogenes has been known to exhibit extensive polyphosphate accumulation, particularly after being subjected to phosphate starvation (Harold, 1966).

Some strains of Acinetobacter that occur predominantly in wastewater are known to accumulate polyphosphate (Deinema et al., 1980; Torein et al., 1990) although they are no longer believed to be the principal bacteria involved in enhanced biological phosphate removal (EBPR) from waste streams (Mino et al., 1998). The microbial removal of phosphate from wastewater is slow and improvements are required to support the industrial application of this physiological trait (Kato et al., 1993b). Further knowledge about the genes involved in polyphosphate synthesis and their regulation in Acinetobacter species will aid in this task. Here, we report on the cloning and characterization of the $p p k$ 
gene from Acinetobacter baumannii 252, isolated from EBPR-performing activated sludge and its transcriptional regulation by phosphate concentration.

\section{METHODS}

Bacterial strains and plasmids. The bacterial strains and plasmids used are shown in Table 1. A. baumannii 252 was isolated from activated sludge and identified using the API (bioMérieux) system for the identification of non-enteric Gram-negative organisms.

Media and growth conditions. E. coli and A. baumannii cells were routinely grown in LB, with $100 \mu \mathrm{g}$ ampicillin $\mathrm{ml}^{-1}$ added when culturing strains containing an ampicillin resistance plasmid. For polyphosphate kinase assays and growth studies, A. baumannii cultures were grown in media containing butyric acid as the sole carbon source, to which phosphate was added as required in the form of $\mathrm{NaH}_{2} \mathrm{PO}_{4}$ (van Veen et al., 1993). For cultures of A. baumannii, high- and low-phosphate media were defined as containing $1 \mathrm{mM}$ and $10 \mu \mathrm{M}$ phosphate, respectively. For Miller assay studies in E. coli, LB was used as the high-phosphate medium $(4 \mathrm{mM})$ and a phosphate-free medium was prepared containing $\left(1^{-1}\right): \mathrm{NH}_{4} \mathrm{Cl}, 1 \mathrm{~g} ; \mathrm{MgSO}_{4}$, $1.2 \mathrm{~g} ; \mathrm{KCl}, 0.75 \mathrm{~g}$; Tris, $6 \mathrm{~g} ; \mathrm{CaCl}_{2} .2 \mathrm{H}_{2} \mathrm{O}(1 \mathrm{M}), 0.4 \mathrm{ml}$; glucose, $5 \mathrm{~g}$; trace element solution $\left(\mathrm{l}^{-1}: \mathrm{MgSO}_{4}, 3.0 \mathrm{~g}\right.$; $\mathrm{MnSO}_{4}, 0.5 \mathrm{~g}, \mathrm{NaCl}, 1.0 \mathrm{~g}, \mathrm{FeSO}_{4} .7 \mathrm{H}_{2} \mathrm{O}, 0.1 \mathrm{~g} ; \mathrm{CoCl}_{2}$, $0 \cdot 1 \mathrm{~g} ; \mathrm{ZnSO}_{4} . \mathrm{H}_{2} \mathrm{O}, 0 \cdot 01 \mathrm{~g} ; \mathrm{CuSO}_{4}, 0 \cdot 1 \mathrm{~g} ; \mathrm{H}_{3} \mathrm{BO}_{3}, 0 \cdot 01 \mathrm{~g}$; $\mathrm{Na}_{2} \mathrm{MoO}_{4} \cdot 2 \mathrm{H}_{2} \mathrm{O}, 0.01 \mathrm{~g}$; $\mathrm{AlK}\left(\mathrm{SO}_{4}\right)_{2} .12 \mathrm{H}_{2} \mathrm{O}, 0.01 \mathrm{~g}$; nitriliotriacetate, $1.5 \mathrm{~g}$; $\mathrm{pH} 6.5), 2 \mathrm{ml}$; $\mathrm{pH} 7 \cdot 2$. For RNA extractions from Acinetobacter for RT-PCR studies, the above medium was used to which phosphate was added as required. To select for recombinant clones, $40 \mu \mathrm{g} \mathrm{X}-\mathrm{Gal} \mathrm{m}{ }^{-1}, 200 \mu \mathrm{g} \mathrm{IPTG} \mathrm{ml}^{-1}$ and $100 \mu \mathrm{g}$ ampicillin $\mathrm{ml}^{-1}$ were added to the media.

Chemicals and enzymes. Hexokinase, glucose-6-phosphate dehydrogenase, $\mathrm{P}^{1}, \mathrm{P}^{5}$-di(adenosine- $\left.5^{\prime}\right)$ pentophosphate, ATP and NADP were purchased from Boehringer Mannheim. Synthetic polyphosphate in the form of Graham salt, which is a mixture of linear sodium polyphosphates $\left(\mathrm{NaPO}_{3}\right)_{\mathrm{n}}$, was prepared by heating $\mathrm{NaPO}_{4}$ for $3 \mathrm{~h}$ in a furnace at $750{ }^{\circ} \mathrm{C}$ (where $\mathrm{n} \sim 10^{2}$ ) (van Groenestijn et al., 1989).

PCR methods. The primer pair olm1/ojc8 (olm1: 5'-GAATTCTCAAGAACTGACAGGTATGG-3' ; ojc8 : 5'-ATCCAG-
TCTGCACTTGAGCAATA-3') was used to amplify a $300 \mathrm{bp}$ product from A. baumannii, which was cloned in pGEM-T. The resulting plasmid was named pJC11. Amplification was performed in a PTC-100 programmable thermal controller (M $\mathrm{J}$ Research) using the following conditions: $95^{\circ} \mathrm{C}$ for 5 min; 30 cycles of $95^{\circ} \mathrm{C}$ for $1 \mathrm{~min}, 52^{\circ} \mathrm{C}$ for $1 \mathrm{~min}$ and $72{ }^{\circ} \mathrm{C}$ for $1 \mathrm{~min}$; and finally $72^{\circ} \mathrm{C}$ for $10 \mathrm{~min}$. The primer pair ojc9/ojc10 (ojc9: 5'-TTCCCTGCTTTCGCAAGCACAAT3'; ojc10: 5'-TTGTGGGACGTTTCCTTGAACATA-3') was used for inverse-PCR on PstI-digested and ligated genomic DNA along with buffer 3 from the Expand kit (Boehringer Mannheim) according to the manufacturer's instructions, with an elongation time of 260 s per cycle. The cloned product was named pJC13. The entire gene was subsequently obtained by PCR using the primer pair olm3/olm4 (olm3: 5'-TACGCTATGATGATTGGTTTG-3' ; olm4 : 5'-TGTTTCATCAGCAGATTATGC-3'). The resulting cloned product was named pJC16. PCR amplification of the promoter region was carried out using the primer pair olm5/olm6 (olm5: $5^{\prime}$ AAGCTTGATTCAAGCAGCGGTATATG-3'; olm6: 5' AAGCTTCCATCAGCCGTTTGTATTC-3'; HindIII sites underlined) and the resulting clone was named pJC20.

For RT-PCR, the reverse transcription reaction was first carried out on $1 \mu \mathrm{g}$ RNA with $1 \mu \mathrm{l} 10 \mathrm{mM}$ Random Primers (Boehringer Mannheim), $1 \mu \mathrm{l} 10 \mathrm{mM}$ dNTPs (Boehringer Mannheim), $2 \mu$ l BSA (1 $\left.\mathrm{mg} \mathrm{ml}^{-1}\right), 4 \mu \mathrm{l} 5 \times$ buffer (Promega), $40 \mathrm{U}$ RNasin and $200 \mathrm{U}$ RT-AMV (Promega). The primer pair olm9/ojs13 (olm9: 5'-ATGGCGATTTTAATGGCGGTA$3^{\prime}$; ojs13 : 5'-GTGCAACCTGTTCCTGAA-3') was then used at an annealing temperature of $52{ }^{\circ} \mathrm{C}$ to carry out the PCR reaction on the $\mathrm{CDNA}$, resulting in a $600 \mathrm{bp} p p k$ gene product, which was sequenced in order to confirm its identity.

Physiology and growth studies. E. coli XL1 containing the construct pJC16 or pGEM-T (negative control) was grown in $10 \mathrm{ml} \mathrm{LB}$ broth overnight. The strains were subsequently subcultured into $500 \mathrm{ml} \mathrm{LB}$ broth to obtain a starting $\mathrm{OD}_{580}$ of $0 \cdot 08$. Growth of the strains was monitored by measuring the optical density and plotting it against time. After $3 \mathrm{~h}$, a $20 \mathrm{ml}$ sample was removed from each flask and centrifuged for $5 \mathrm{~min}$ at $5000 \mathrm{~g}$. IPTG $\left(200 \mu \mathrm{l}\right.$ of a solution containing $\left.200 \mathrm{mg} \mathrm{ml}^{-1}\right)$ was added to the remaining culture. Over the following $6 \mathrm{~h}$,

Table 1. Bacterial strains and plasmids

\begin{tabular}{|c|c|c|}
\hline Strain or plasmid & Relevant characteristics & Origin/reference \\
\hline \multicolumn{3}{|l|}{ Strains } \\
\hline E. coli XL1 & Allows blue/white screening on X-Gal & $\begin{array}{l}\text { Sambrook et al. } \\
\text { (1989) }\end{array}$ \\
\hline E. coli TG1 & Allows blue/white screening on X-Gal & $\begin{array}{l}\text { Sambrook et al. } \\
(1989)\end{array}$ \\
\hline A. baumannii 252 & Activated sludge isolate & Primus (1998) \\
\hline \multicolumn{3}{|l|}{ Plasmids } \\
\hline pGEM-T & Cloning vector for PCR products, $\mathrm{Ap}^{\mathrm{R}}$ & Promega \\
\hline Topo TA & Cloning vector for PCR products, $\mathrm{Ap}^{\mathrm{R}}$ & Invitrogen \\
\hline pQF52 & Vector containing promoterless lac Z gene, $\mathrm{Ap}^{\mathrm{R}}$ & McLean et al. (1997) \\
\hline pJC11 & pGEM-T containing $300 \mathrm{bp}$ PCR product of $p p k$ gene obtained with olm1/ojc8 & This work \\
\hline pJC13 & Inverse-PCR product of $3 \mathrm{~kb}$ in pGEM-T & This work \\
\hline pJC16 & Full-length $p p k$ gene $(2 \mathrm{~kb})$ in pGEM-T & This work \\
\hline pJC20 & Promoter region ( 800 bp) obtained by PCR with olm5/olm6 in pQF52 HindIII site & This work \\
\hline
\end{tabular}


$20 \mathrm{ml}$ samples were removed at hourly intervals. After resuspension in $1 \mathrm{ml}$ sonication buffer $(0 \cdot 1 \mathrm{mM}$ EDTA, $50 \mathrm{mM}$ Tris/ $\mathrm{HCl} \mathrm{pH} \mathrm{7 \cdot 0,} 1 \mathrm{mM}$ 2-mercaptoethanol), the cells were sonicated three times at $60 \mathrm{~W}$ for $15 \mathrm{~s}$ with $45 \mathrm{~s}$ intervals. The cell lysates were centrifuged at $10000 \mathrm{~g}$ for $3 \mathrm{~min}$ in a microfuge and the supernatant was stored at $-20^{\circ} \mathrm{C}$. The total protein content was determined using the Bradford (1976) assay.

Assays and nucleic acid isolation and manipulations. The assay for polyphosphate kinase activity described by van Groenstijn et al. (1989) was used. Specific activity values were expressed in nmol $\min ^{-1}$ (mg protein $)^{-1}$. Phosphate concentrations were determined according to a previously described method (Martin \& Tolbert, 1983). The Miller (1972) assay was used for measuring $\beta$-galactosidase activity.

Genomic and plasmid DNA were prepared as previously described (Sambrook et al., 1989). Alternatively, commercial miniprep kits (Qiagen) were used to obtain plasmid DNA for sequencing. For cloning experiments, either pGEM-T or the Topo TA cloning vectors were used. Restriction enzymes were purchased from Promega or Boehringer Mannheim and used according to the manufacturers' instructions. For detection of promoter activity, the promoter-probe vector pQF52 was used (McLean et al., 1997). For transformations, E. coli cells were electroporated as previously described (Sambrook et al., 1989). DNA sequence was determined by the dideoxy chain-termination method (Sanger et al., 1977) using the DyeDeoxy Terminator Cycle Sequencing Ready Reaction kit with AmpliTaq DNA polymerase (Applied Biosystems) in a Gene Amp PCR system L400 (Perkin Elmer) and run on an automated DNA sequencer (model 373 STRETCH, Applied Biosystems). The sequencing strategy consisted of the initial use of universal M13 primers, followed by the design of primers using the newly acquired sequences. Sequence data were assembled and processed using the DNA STAR software package (DNA STAR, Madison, WI, USA). The BLAST algorithm was used to search DNA and protein databases for similarity.

RNA was prepared following the method outlined by Ausubel et al. (1987). Contaminating DNA was then digested with DNase according to the manufacturer's instructions (Boehringer Mannheim). Primer extension analysis was carried out as described by Engelke et al. (1992). The fmol DNA Sequencing system (Promega) was used for the sequencing reaction to be run alongside the primer extension product. The sequence of the $p p k$-specific primer used was $5^{\prime}$-GGGGAGGCTTGTGTAACTA-3'.

\section{RESULTS}

\section{Phosphate uptake by growing cultures of A. baumannii}

A. baumannii cultures were inoculated from highphosphate overnight cultures into both high- and lowphosphate butyric acid media. An initial increase in the extracellular phosphate concentration was detected in the low-phosphate medium (Fig. 1a) but not in the highphosphate medium (Fig. 1b). This increase could be explained as a release of phosphate by the cells due to the stress involved in growing under phosphate-limiting conditions. This initial release of phosphate by stressed cultures preceding phosphate uptake has been welldocumented for poly $(\mathrm{P})$-accumulating Acinetobacter spp. (Ohtake et al., 1985). The A. baumannii culture grown under low-phosphate conditions removed phos-

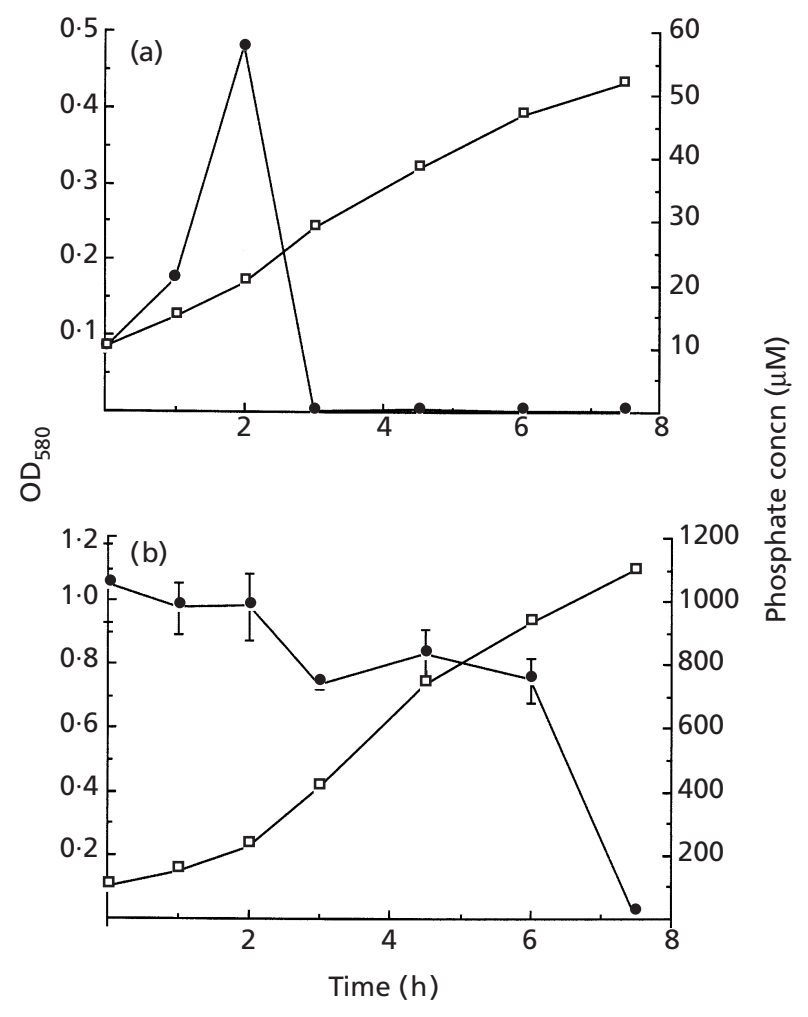

Fig. 1. Growth $(\square)$ and extracellular phosphate concentration (b) of $A$. baumannii cultures grown under low- (a) and high(b) phosphate conditions.

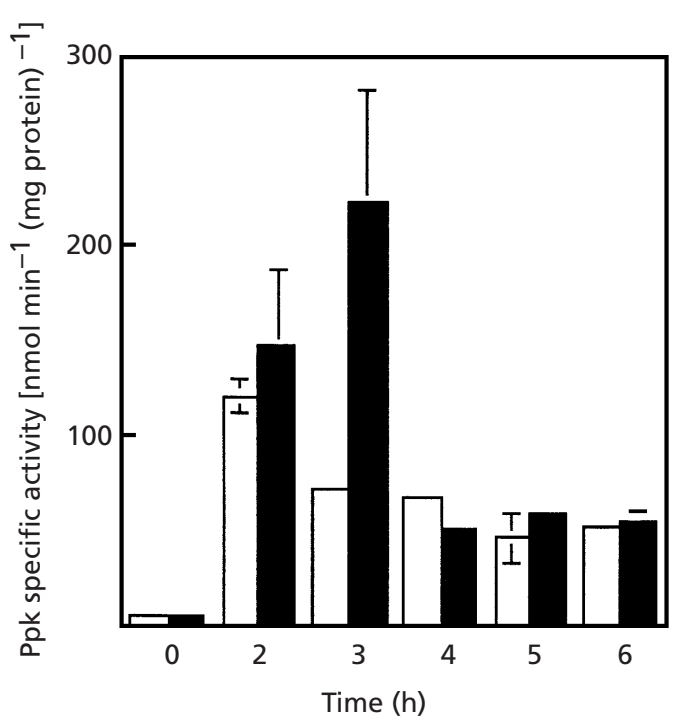

Fig. 2. Specific activity of polyphosphate kinase from $A$. baumannii cells grown under low- $(\boldsymbol{\square})$ and high- $(\square)$ phosphate conditions.

phate from the media to undetectable levels within $3 \mathrm{~h}$ and this corresponded to maximal expression of polyphosphate kinase (Ppk) activity between 2 and $3 \mathrm{~h}$ for the low-phosphate culture as seen in Fig. 2. 


\section{Cloning of the ppk gene from $A$. baumannii strain 252}

Alignments of the previously cloned $p p k$ gene sequences of Acinetobacter sp. strain ADP1, E. coli, Pseudomonas aeruginosa, K. aerogenes and N. meningitidis were used to choose conserved regions to which PCR primers could be designed. The primers chosen (olm1/ojc8) gave rise to a $300 \mathrm{bp}$ PCR fragment of the polyphosphate kinase gene, which was sequenced. Based on this sequence, primers (ojc9/ojc10) were then designed facing outwards from each other in order to amplify the rest of the gene using inverse-PCR. PCR with these primers on PstI-digested and ligated genomic DNA led to the generation of a product of approximately $3 \mathrm{~kb}$. This was cloned in pGEM-T and sequenced. Because of the nature of inverse-PCR, the resulting clone contains the gene divided into non-contiguous parts and so the gene was subsequently cloned in its entirety for expression studies using the primer pair olm3/olm4.

\section{Sequence analysis of the ppk gene}

The $p p k$ gene was found to be $2079 \mathrm{bp}$ in length and to have a GC content of $39 \mathrm{~mol} \%$, which is typical of Acinetobacter (Henriksen, 1976). The ppk gene encodes a putative protein of 692 amino acids, compared with 691 in Acinetobacter sp. strain ADP1, 688 in E. coli and 685 in both N. meningitidis and $K$. aerogenes. An identity of $77 \%$ was found at the nucleotide level and $82 \%$ at the amino acid level with strain ADP1. There was $33 \%$ identity between A. baumannii and both $K$. aerogenes and E. coli at the amino acid level and 50\% between A. baumannii and N. meningitidis.

\section{Induction of polyphosphate kinase enzyme activity in $E$. coli cells transformed with the cloned ppk gene}

E. coli cells containing the cloned $p p k$ gene on a plasmid (pJC16) under the control of the lac Z promoter or the vector alone (pGEM-T) (as a negative control), were grown for $3 \mathrm{~h}$ before the addition of IPTG. Two hours after induction, a 333-fold increase in Ppk activity $\left[100 \mathrm{nmol} \mathrm{min}{ }^{-1}(\mathrm{mg} \text { protein })^{-1}\right]$ was detected with the pJC16 cells relative to those containing the negative

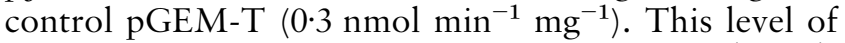
Ppk activity remained high at $5 \mathrm{~h}\left(102 \mathrm{nmol} \mathrm{min}^{-1} \mathrm{mg}^{-1}\right)$ and at $7 \mathrm{~h}\left(88 \mathrm{nmol} \mathrm{min}{ }^{-1} \mathrm{mg}^{-1}\right)$ following induction. Detection of significantly higher levels of Ppk activity in E. coli transformed with pJC16 suggested that we had cloned a functional $p p k$ gene.

\section{Promoter studies}

An 800 bp fragment including the start of the $p p k$ gene and approximately 400 bp upstream of the coding region was cloned into the promoter-probe vector pQF52. The ligation mixture was electroporated into E. coli TG1 cells. Cells containing the resulting construct, named pJC20, were grown under conditions of phosphate limitation and phosphate excess and up to 11-fold more $\beta$-galactosidase activity was found under phosphate-

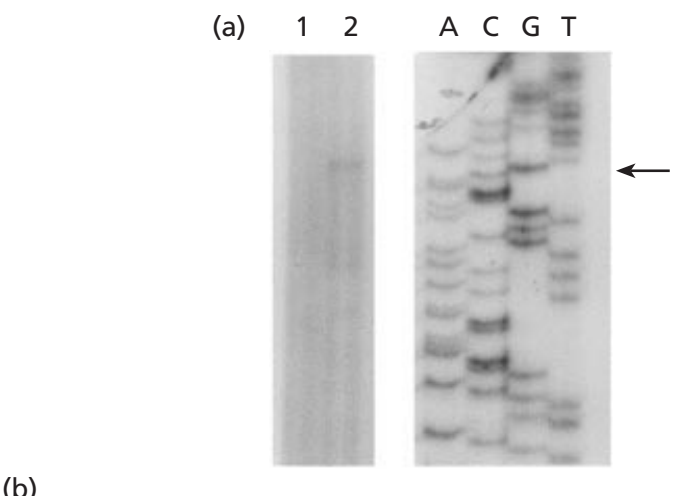

(b)

GATTCAAGCAGCGGTATATGGCTTGAATGTAGTGTTGGGTGATAGCGGTTTGATTATTGGGGCATT CTTCGCTTCTTTATTTGAAGTGCATGCCGCCATGGCAACGGTGGTGATGCAAGGAACACCACAGCA GATGACGTTGGTCTACGCTATGATGATTGGTTGGCTGCACATGCATTTTCTAAAAGCATCAATGC ATITTAACTGGTGGCGGGAAATATTTTCTATATITTGCCCCCGCACAAATGCTGCATATGGCGAT TITAATGGCGGTACTTGGATGGTTATTCAGTAAATTAGGATTTATTTTCAATATTTTAGAATGG

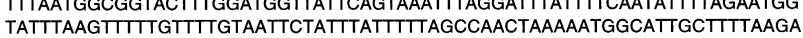
TATTTAAGTTTTTGTTTTGTA

Fig. 3. Mapping the $5^{\prime}$ start site of ppk mRNA by primer extension analysis. (a) RNA was prepared from exponentially grown cells under high- (lane 1) or low- (lane 2) phosphate conditions. Lanes $A, C, G$ and $T$ show the sequencing products obtained with the same primer. The arrow indicates the start site of transcription. (b) The sequence shown in (a) is underlined up to the start site, which is indicated in bold type. The translational start site ATG is shown in bold italics.

limiting conditions (148 Miller units) compared with those of phosphate excess (13 Miller units). This increased $\beta$-galactosidase activity was due to the presence of the $p p k$ promoter fragment since cells containing the promoterless vector pQF52 assayed under similar conditions showed no induction of $\beta$-galactosidase under low-phosphate conditions (8 Miller units). Primer extension analysis was carried out in order to map the transcription start site. This was found to be within the fragment cloned in pJC20 (Fig. 3). In a further experiment, 5'-RACE (rapid amplification of cDNA ends) indicated the presence of a second transcriptional start site $222 \mathrm{bp}$ upstream from this site, not contained within the pJC20 clone. This start site was also seen following primer extension studies under both high- and lowphosphate conditions (data not shown).

\section{Induction of ppk transcription by phosphate starvation}

RNA was isolated from A. baumannii cells grown under conditions of phosphate limitation and phosphate excess. Samples were taken in the exponential phase and again in the stationary phase. RT-PCR was then carried out using the primer pair olm9/ojs13 and $5 \mu$ laliquots of each reaction were electrophoresed on $1 \%$ agarose gels and the product band intensities within each experiment were visually compared after ethidium bromide staining. Transcripts were detected under low- but not under high-phosphate conditions for the exponential-phase cells. In stationary-phase cells from the high-phosphate culture, no transcripts were detected, while there were still detectable transcripts in the low-phosphate cells at 
(a)

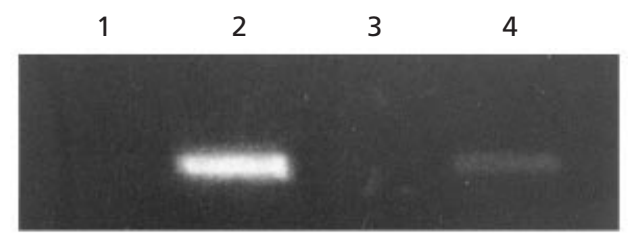

1

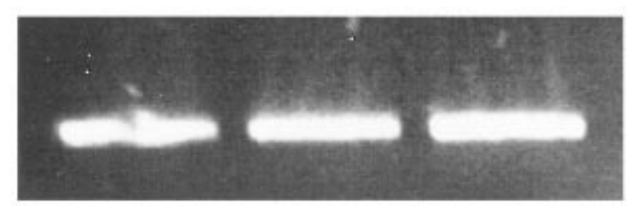

1

(c)

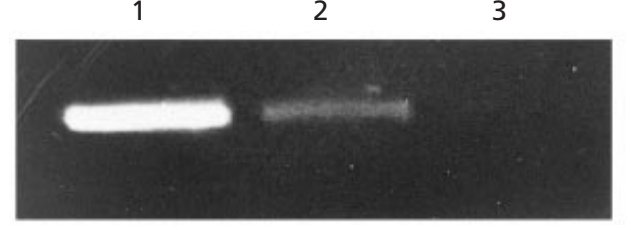

Fig. 4. (a) RT-PCR on exponential- and stationary-phase cells cultured under high- and low-phosphate conditions. Lanes 1 and 2, exponential-phase cells grown in high- and lowphosphate media, respectively; lanes 3 and 4, stationary-phase cells grown in high- and low-phosphate media, respectively. (b) RT-PCR products obtained from an $A$. baumannii culture grown under low-phosphate conditions with samples taken at 2, 4 and $6 \mathrm{~h}$ shown in lanes 1, 2 and 3, respectively. (c) RT-PCR products obtained from an $A$. baumannii culture initially grown under low-phosphate conditons and phosphate then added back into the culture after $2 \mathrm{~h}$, with samples taken at 2, 4 and $6 \mathrm{~h}$ shown in lanes 1, 2 and 3, respectively.

the same time point (Fig. 4a). These results indicate that regulation of expression of the $p p k$ gene in A. baumanii is due to phosphate limitation and not due to limitations in other nutrients. This confirms the results obtained for the $p p k$ promoter in E. coli, which was selectively induced under low-phosphate growth conditions.

In a further experiment, two similar flasks of phosphatefree media were inoculated from overnight high-phosphate cultures. Samples were removed from one culture after 2, 4 and $6 \mathrm{~h}$. For the other culture, the first sample was taken after $2 \mathrm{~h}$, then phosphate was added back into the media at a final concentration of $1 \mathrm{mM}$. Subsequent samples were taken after 4 and $6 \mathrm{~h}$. RNA was extracted from the six samples and RT-PCR was performed using the primer pair olm9/ojs13. The results of the RT-PCR showed transcripts at all three time points for the first culture, which had been maintained under low-phosphate conditions throughout (Fig. 4b). In the second culture, transcripts were detected at $2 \mathrm{~h}$, but, following the introduction of phosphate to the media, a marked reduction in transcript levels was observed (Fig. 4c).

Samples were also taken to simultaneously measure polyphosphate kinase enzyme activity. The specific activity was found to be 26.4 and $29.6 \mathrm{nmol} \mathrm{min} \mathrm{min}^{-1}$ $(\mathrm{mg} \text { protein })^{-1}$ at 2 and $4 \mathrm{~h}$, respectively, for the low- phosphate culture. However, following addition of phosphate to the second culture after $2 \mathrm{~h}$ when Ppk activity was $34.8 \mathrm{nmol} \mathrm{m^{-1 }}(\mathrm{mg} \text { protein })^{-1}$, the activity dropped to $13.9 \mathrm{nmol} \mathrm{m^{-1 }}(\mathrm{mg} \text { protein })^{-1}$.

\section{DISCUSSION}

In this study, we report on the cloning and characterization of the $p p k$ gene from A. baumannii 252, which was isolated from an EBPR-performing activated sludge. The $p p k$ gene encodes a putative protein with a high degree of similarity to previously described $p p k$ genes. We demonstrate that transcription of $p p k$ is regulated by phosphate concentration, and we show promoter activity from a cloned fragment upstream from the $p p k$ gene.

The nature and properties of inorganic phosphate uptake/transport systems have been well-documented in E. coli (Rosenberg et al., 1977; Willsky \& Malamy, 1980). In Acinetobacter johnsonii, two phosphate transport systems have been characterized and they resemble those of E. coli. One is an inducible, high-affinity transport system and the other is a constitutive lowaffinity transport system. Experiments carried out on $A$. johnsonii suggest the presence of a similar regulatory mechanism to the pho regulon in E. coli for reducing extracellular phosphate concentrations to micromolar levels (van Veen et al., 1993).

To determine whether or not A. baumannii could take up phosphate when grown aerobically, its growth was studied under both high- and low-phosphate conditions and Ppk activity was measured. Growth studies showed an initial release of phosphate in the low-phosphate media. This phenomenon has previously been reported in both pure cultures of Acinetobacter calcoaceticus (Ohtake et al., 1985) and EBPR-performing bacteria in activated sludge following an anaerobic period (Korstee et al., 1994). This initial release was followed by the uptake of phosphate from the media leading to undetectable extracellular levels within $3 \mathrm{~h}$, which corresponded to maximal Ppk activity between 2 and $3 \mathrm{~h}$ for the low-phosphate culture.

In E. coli, the $p p k$ gene is part of a two-gene operon together with exopolyphosphatase $(p p x)$. The latter functions to degrade poly $(\mathrm{P})$ granules to provide ATP to the E. coli cell (Akiyama et al., 1993). However, to date this gene has not been identified in any Acinetobacter species. Even if present, it does not appear to be located in the same operon as the $p p k$ gene in either A. calcoaceticus (Geißdörfer et al., 1998) or in A. baumannii (data not shown).

We have shown that the region upstream of the $p p k$ gene functions as a phosphate-regulated promoter in the heterologous E. coli host. Primer extension analysis with mRNA from cells grown in low-phosphate media located the transcription start site within the promoter region cloned in pJC20 (Fig. 3). Furthermore, $5^{\prime}$-RACE showed the presence of a second transcription start site upstream of the first one. This was seen in primer 
extension analysis in both high- and low-phosphategrown cells, suggesting that it is a constitutive promoter. A second constitutive promoter was also reported to be present in Acinetobacter sp. strain ADP1; however here it was located downstream from the inducible one (Geißdörfer et al., 1998). The functioning of the $A$. baumannii ppk promoter in E. coli and its induction under low-phosphate conditions suggests that a common type of transcriptional control mechanism may be in operation in both organisms. In E. coli, PhoB is the transcriptional activator for Pho-regulated genes, and in addition PhoB has been shown to function as a transcriptional activator for Ppk activity in K. aerogenes (Kato et al., 1993a). It is possible that a PhoB or a PhoBlike transcription factor is also present in A. baumannii which regulates transcription from the $p p k$ promoter given that this promoter appears to be functional in $E$. coli where it is selectively induced (11-fold induction) under low-phosphate conditions. If a similar system is in operation in A. baumannii, then we might expect to see a pho box or pho-box-like sequence in the promoter region. However, no sequences similar to the pho box consensus sequence derived from E. coli and K. aerogenes phosphate-regulated promoters (Kato et al., 1993b) appears to be present. Similarily, no pho boxes appear to be present in the promoter region of the Acinetobacter sp. strain ADP1 ppk gene (Geißdörfer et al., 1998).

While no $p h o B$ or $p h o R$ genes have as yet been cloned from Acinetobacter species, it appears likely that genes with homology to $p h o B R$ do exist in this genus. For instance, in Acinetobacter strain RA3849, the promoter for the polyhydroxyalkanoic acid biosynthetic genes has been shown to be induced by phosphate starvation and a putative pho box was located in the promoter region (Schembri et al., 1995).

Further proof for the regulation of $p p k$ transcription in A. baumannii by phosphate was obtained using RTPCR. $p p k$ transcripts were detected in cells grown under phosphate-limiting conditions but not under conditions of phosphate excess. In stationary-phase cells, no transcripts were detected for the high-phosphate culture, indicating that expression is not induced in stationary phase but depends specifically on phosphate limitation.

ppk transcription in A. baumannii was repressed by the addition of phosphate back into the culture media (Fig. $4 \mathrm{~b}$ and c) indicating an additional level of complexity with respect to the regulation of phosphorus metabolism in this strain. In E. coli, under conditions of excess environmental phosphate the PhoR protein sensor kinase cannot phosphorylate PhoB, leaving it in an inactive unphosphorylated form (Torriani-Gorini, 1994). If a similar system is in operation here, then PhoB would again appear a likely candidate in mediating such a repressive effect on $p p k$ transcription. However, further genetic characterization of the $p p k$ promoter region will be necessary to determine if this is in fact the case. The data presented here support the view that phoBR-like genes are likely to exist in Acinetobacter species and that PhoB or a PhoB-homologue may be involved in mediating the transcriptional regulation of the $p p k$ gene in A. baumannii.

\section{ACKNOWLEDGEMENTS}

This work was funded by the Irish Department of Agriculture, Food and Forestry, under the food industry subprogramme of the EU structural funds 1994-9. We thank A. Kropinsky, W. Geißdörfer, C. Martín and L. López for providing strains and plasmids.

\section{REFERENCES}

Ahn, K. \& Kornberg, A. (1990). Polyphosphate kinase from Escherichia coli. J Biol Chem 265, 11734-11739.

Akiyama, M. E., Crooke, E. \& Kornberg, A. (1992). The polyphosphate kinase gene of Escherichia coli. Isolation and sequence of the $p p k$ gene and membrane location of the protein. J Biol Chem 268, 633-639.

Akiyama, M. E., Crooke, E. \& Kornberg, A. (1993). An exopolyphosphatase of Escherichia coli. The enzyme and its $p p x$ gene in a polyphosphate operon. J Biol Chem 268, 633-639.

Ausubel, F. M., Brent, R., Kingston, R. E., Moore, D. D., Seidman, J. G., Smith, J. A., \& Struhl, K. (1987). Current Protocols in Molecular Biology. New York: Greene Publishing Associates \& Wiley Interscience.

Bradford, M. M. (1976). A rapid and sensitive method for the quantitation of microgram quantities of protein utilizing the principle of protein-dye binding. Anal Biochem 72, 248-254.

Castuma, C. E., Huang, R., Kornberg, A. \& Reusch, R. N. (1995). Inorganic polyphosphates in the aquisition of competence in Escherichia coli. J Biol Chem 270, 12980-12983.

Deinema, M. H., Habets, L. H. A., Scholten, J., Turksta, E. \& Webers, H. A. A. M. (1980). The accumulation of polyphosphate in Acinetobacter spp. FEMS Microbiol Lett 9, 275-279.

Engelke, G., Gutowski-Eckel, Z., Hammelmann, M. \& Entian, K.-D. (1992). Biosynthesis of the lantiobiotic nisin: genomic organization and membrane localization of the NisB protein. Appl Environ Microbiol 58, 3730-3743.

Geißdörfer, W., Rarajczak, A. \& Hillen, W. (1998). Transcription of $p p k$ from Acinetobacter sp. strain ADP1, encoding a putative polyphosphate kinase, is induced by phosphate starvation. Appl Environ Microbiol 64, 896-901.

van Groenestijn, J. W., Bentvelsen, M. M. A., Deinema, M. H. \& Zehnder, A. J. B. (1989). Polyphosphate-degrading enzymes in Acinetobacter species and activated sludge. Appl Environ Microbiol 55, 219-223.

Harold, F. M. (1966). Inorganic polyphosphate in biology: structure, metabolism and function. Bacteriol Rev 30, 772-794.

Henriksen, S. D. (1976). Moraxella, Neisseria, Brahmella and Acinetobacter. Annu Rev Microbiol 30, 63-83.

Kato, J., Yamada, K., Muramatsu, A., Hardoyo \& Ohtake, H. (1993a). Genetic improvement of Escherichia coli for enhanced biological removal of phosphate from wastewater. Appl Environ Microbiol 59, 3744-3749.

Kato, J., Yamamoto, T., Yamada, K. \& Ohtake, H. (1993b). Cloning, sequence and characterization of the polyphosphateencoding gene ( $p p k$ ) of Klebsiella aerogenes. Gene 137, 237-242.

Keasling, J. D. \& Hupf, G. A. (1996). Genetic manipulation of polyphosphate metabolism affects cadmium tolerance in Escherichia coli. Appl Environ Microbiol 62, 743-746. 
Kornberg, A. (1995). Inorganic polyphosphate: toward making a forgotten polymer unforgettable. J Bacteriol 177, 491-496.

Korstee, K. J. J., Appledoorn, K. J., Bonting, C. F. C., van Niel, E. W. J. \& van Veen, H. W. (1994). Biology of polyphosphateaccumulating bacteria involved in enhanced biological phosphorus removal. FEMS Microbiol Rev 15, 137-153.

Kulaev, I. S. (1979). The Biochemistry of Inorganic Polyphosphates. New York: Wiley.

McLean, B. W., Wiseman, S. L. \& Kropinski, A. M. (1997). Functional analysis of $\sigma-70$ consensus promoters in Pseudomonas aeruginosa and Escherichia coli. Can J Microbiol 43, 981-985.

Martin, F. \& Tolbert, N. E. (1983). Factors which affect the amount of inorganic phosphate, phosphorylcholine and phosphorylethanolamine in xylem exudate of tomato plants. Plant Physiol 73, 464-470.

Miller, J. H. (1972). Experiments in Molecular Genetics. Cold Spring Harbor, NY: Cold Spring Harbor Laboratory.

Mino, T., van Loosdrecht, M. C. M. \& Heijnen, J. J. (1998). Microbiology and biochemistry of the enhanced biological phosphate removal process. Water Res 11, 3193-3207.

Ohtake, H., Takahashi, K., Tsuzuki, Y. \& Toda, K. (1985). Uptake and release of phosphate by a pure culture of Acinetobacter calcoaceticus. Water Res 19, 1587-1594.

Primus, D. J. (1998). Efficient biological nutrient removal from wastewater streams in the Irish food industry. MSc thesis, National University of Ireland, Cork.

Reusch, R. N. \& Sadoff, H. L. (1988). Putative functions and structures of a $\beta$-hydroxybutyrate/calcium polyphosphate channel in bacterial plasma membranes. Proc Natl Acad Sci USA 85, 4176-4180.

Rosenberg, H., Gerdes, H. R. G. \& Chegwidden, K. (1977). Two systems for the uptake of phosphate in Escherichia coli. J Bacteriol 131, 505-511.
Sambrook, J., Fritsch, E. F. \& Maniatis, T. (1989). Molecular Cloning: a Laboratory Manual, 2nd edn. Cold Spring Harbor, NY : Cold Spring Harbor Laboratory.

Sanger, F., Nicklen, S. \& Coulson, A. R. (1977). DNA sequencing with chain-terminating inhibitors. Proc Natl Scad Sci USA 74, 5463-5467.

Schembri, M. A., Bayly, R. C. \& Davies, J. K. (1995). Phosphate concentration regulates transcription of the Acinetobacter polyhydroxyalkanoic acid biosynthetic genes. J Bacteriol 177, 4501-4507.

Torein, D. F., Gerber, A., Lotter, L. H. \& Cloete, T. E. (1990). Enhanced biological phosphorus removal in activated sludge systems. Adv Microb Ecol 11, 173-230.

Torriani-Gorini, A. (1994). Regulation of phosphate metabolism and transport. In Phosphate in Microorganisms, pp. 1-4. Edited by A. Torriani-Gorini, E. Yagil \& S. Silver. Washington, DC: American Society for Microbiology.

van Veen, H. W., Abee, T., Kortstee, G. J. J., Konings, W. N. \& Zehnder, A. J. B. (1993). Characterization of two phosphate transport systems in Acinetobacter johnsonii 210A. J Bacteriol 155, 200-206.

Wanner, B. L. (1996). Phosphorus assimilation and control of the phosphate regulon. In Escherichia coli and Salmonella: Cellular and Molecular Biology, 2nd edn, vol. I, pp. 1357-1381. Edited by F. C. Neidhardt and others. Washington, DC: American Society for Microbiology.

Willsky, G. R. \& Malamy, M. H. (1980). Characterization of two genetically separable inorganic phosphate transport systems in Escherichia coli. J Bacteriol 144, 356-365.

Wood, H. G. \& Clark, J. E. (1988). Biological aspects of inorganic polyphosphates. Annu Rev Biochem 57, 235-260.

Received 25 January 1999; revised 30 April 1999; accepted 7 June 1999. 